HENRYK OLSZEWSKI

KRYSTYNA SIKORSKA-DZIĘGIELEWSKA

\title{
Poznańskie środowisko historycznoprawne w latach 1919-1939
}

\section{Posener Kreis der Rechtshistoriker 1919-1939}

1. Powstawanie. 2. Struktury i pierwsza obsada stanowisk. 3. Personalia. 4. Dorobek. 5. Funkcje. 6. Uczniowie.

1. Gründung. 2. Strukturen und die erste Postenbesetzung. 3. Personalien. 4. Errungenschaften. 5. Ausgeübte Funktionen. 6. Nachfolger.

1. Wydział Prawa był od początku integralną częścią Uniwersytetu Poznańskiego!. Rozpoczął dzialalność 7 maja 1919 r., czyli tego samego dnia, w którym otworzyl podwoje Uniwersytet, co świadczy o spolecznym zapotrzebowaniu - lączono $\mathrm{z}$ nim bowiem wielkie nadzieje $\mathrm{i}$ oczekiwania, tym większe, że w regionie dotąd nie było polskiego szkolnictwa wyższego. Ksztaltowal się w ciężkich warunkach: brakowało infrastruktury i środków, a regulacje prawne tworzone przez władze b. Dzielnicy Pruskiej nosiły znamiona improwizacji; istniały też poważne trudności ze skompletowaniem kadry naukowej. Dlatego tym wyżej cenić trzeba fakt, że kierownictwa Uczelni i Wydziału potrafily się wznieść ponad lokalne ambicje i partykularyzmy. Wydzial powstawal sprawnie, ale bez pośpiechu, a jego organizator i pierwszy dziekan - Antoni Peretiatkowicz, dbał o to, by stanowił jednostkę uniwersytecką, a nie centrum kształcenia zawodowego

\footnotetext{
Pierwszym aktem prawnym mówiącym o utworzeniu uniwersytetu w Poznaniu było obwieszczenie Komisariatu Naczelnej Rady Ludowej z 30 I 1919 r. Rozporządzeniem Komisariatu NRL z $10 \mathrm{~V} 1919$ r. nadano uniwersytetowi w Poznaniu nazwę: Wszechnica Piastowska. $\mathrm{Na}$ wniosek Senatu rozporządzeniem Ministra Wyznan Religijnych i Oświecenia Publicznego z 10 IV 1920 r. zmieniono nazwę z Wszechnicy Piastowskiej na Uniwersytet Poznański (por. Dziennik Urzędowy Ministerstwa b. Dzielnicy Pruskiej nr 24 z 26 V 1920 r.). Wydział przez pierwsze dwa lata nosił nazwę Wydziału Prawa i Nauk Ekonomiczno-Politycznych, a od 1921 r. - Wydziału Prawno-Ekonomicznego.
} 
- czyli, by przyszli prawnicy byli nie tylko profesjonalistami w zawodzie, ale i humanistami wyposażonymi $w$ wiedzę ogólną, historyczną i teoretyczną. Za wzór posłużyły uniwersytety francuskie i niemieckie, przede wszystkim zaś próbowano zbudować studia sprawdzone już na uniwersytetach galicyjskich we Lwowie i Krakowie, skąd wywodziła się większość profesorów - założycieli Wydziału. Humanistyczny profil studiów prawniczych od początku potwierdzała obecność wśród wykładowców obu sekcji Wydziału wybitnych przedstawicieli dyscyplin pokrewnych, humanistów o ugruntowanej renomie. Byli wśród nich socjologowie Florian Znaniecki i Tadeusz Szczurkiewicz, geografowie oraz ekonomiści Florian Barciński, Stanisław Pawłowski i Stanisław Nowakowski, historyk Kazimierz Tymieniecki ${ }^{2}$. Humanistyczne oblicze Uczelni oraz wysokie wymagania stawiane kadrze sprzyjały poczesnemu miejscu historii prawa w programie studiów prawniczych $\mathrm{i}$ tkwily $u$ podstaw tworzenia się $\mathrm{w}$ latach dwudziestych $\mathrm{i}$ trzydziestych silnego środowiska historycznoprawnego nad Wartą ${ }^{3}$.

2. Zacznijmy od struktur, w jakich rodziły się i rozwijały poszczególne dyscypliny historycznoprawne na Wydziale, w strukturach bowiem znajdowal wierne odzwierciedlenie rozwój poznańskiego środowiska historycznoprawnego.

Wśród czterech nominacji na kierowników katedr na Wydziale, jakie 7 maja 1919 r. wręczył Adam Poszwiński - członek Komisariatu Naczelnej Rady Ludowej, czyli najwyższych władz b. Dzielnicy Pruskiej - dwie przypadły historykom prawa: Zygmunt Lisowski zostal powołany na stanowisko kierownika Katedry Prawa Rzymskiego, Jan Rutkowski zaś został kierownikiem Katedry Historii Gospodarczej. Lisowski, od 1 kwietnia 1919 r. członek Komisji organizacyjnej UP, uzyskał od razu profesure zwyczajną; Rutkowski - badacz dziejów gospodarczych i społecznych, ale $i$ historyk prawa, posiadający veniam legendi, w tej dyscyplinie na Wydziale

\footnotetext{
${ }^{2}$ Por. Kronika Uniwersytetu Poznańskiego za lata 1919-1923, Poznań 1925, passim, oraz Uniwersytet Poznanski w pierwszych latach swego istnienia (1919-1923) za rektoratu Heliodora Święcickiego. Ksiega Pamiqtkowa, red. A. Wrzosek, Poznań 1925, s. 144 i n.

${ }^{3}$ Odtworzenie historii Wydziału i powstawania w nim środowiska historycznoprawnego jest trudne i tylko częściowo możliwe, albowiem stan zachowanych źródeł jest wysoce niezadowalający. Kroniki uczelni i syntetyczne opracowania jej dziejów są niedokładne i nie poświęcaja Wydziałowi należytej uwagi. Nie zachowały się protokoły posiedzeń Rady Wydziału ani materiały $\mathrm{z}$ działalności katedr, zakładów i seminariów, a akta osobowe pracowników są niekompletne. Choć literatura o historii Wydziału jest już wcale pokaźna (jej wykaz u H. Olszewskiego, Wydzial Prawa w latach 1919-1990, RPEiS 1999, t. LXI, z. 2, s. 1-16), brak opracowania interesującego nas tematu. W niniejszym tekście wykorzystaliśmy materiał znajdujący się w Archiwum UAM oraz w zbiorach Biblioteki Raczyńskich, sięgneliśmy do nielicznych wspomnień, do nekrologów drukowanych w CPH i RPEiS, czerpaliśmy $\mathrm{z}$ bogatej twórczości mistrzów okresu między wojnami.
} 
Prawa i Umiejętności Politycznych Uniwersytetu Jana Kazimierza, który przyszedl jako profesor nadzwyczajny - zostal już po roku mianowany profesorem zwyczajnym, a jego katedrę podniesiono do rangi katedry zwyczajnej $j^{4}$. Obie katedry utrzymaly swój status i swoich kierowników do września $1939 \mathrm{r}$.

Nie od razu obsadzona została Katedra Historii Ustroju i Prawa Polskiego. Przedmiot o tej nazwie wykładał w semestrze letnim $1919 \mathrm{r}$. Kazimierz Tymieniecki - profesor Wydziału Filozoficzno-Historycznego UP, zaś od 15 września 1919 r. dojeżdżający z Krakowa i wykładający także prawo kościelne dr Abdon Kłodziński - archiwista VII klasy plac w Krajowym Archiwum Ziemskim w Krakowie. Kłodziński zgodził się wykładać $w$ Poznaniu $w$ charakterze zastępcy profesora, mimo realnych widoków na objęcie Katedry na Uniwersytecie Jagiellońskim. Stąd Rada Wydziału UP usilnie zabiegala o pozyskanie go na stałe. Senat UP, uchwałą z 28 kwietnia 1922 r., po zapoznaniu się ze sprawozdaniem Komisji Wydziałowej (jej członkami byli Edward Taylor, Alfred Ohanowicz i Jan Rutkowski) oraz opiniami Stanisława Kutrzeby, Stefana Ehrenkreutza i Oswalda Balzera, poparł wniosek Rady i wystąpił do Ministra Wyznań Religijnych i Oświecenia Publicznego o powołanie A. Kłodzińskiego na kierownika Katedry Historii Ustroju i Prawa Polskiego w charakterze profesora nadzwyczajnego ${ }^{5}$. Zabiegano o szybkie zatwierdzenie spodziewanej nominacji u Naczelnika Państwa. Wysiłki Wydziału zostały uwieńczone sukcesem, ale stabilizacja na stanowisku kierownika Katedry nie nastąpiła, gdyż już na początku 1924 r. Uniwersytet Jagielloński postanowił powołać Kłodzińskiego na II Katedrę Dawnego Prawa Polskiego w Krakowie, i w związku z tym trzeba było całe postępowanie konkursowe zaczynać od nowa. Z zachowanej korespondencji wynika, że Józef Rafacz i Stefan Grażyński nie byli zainteresowani przyjściem do Poznania, a ponieważ Adam Vetulani nie miał jeszcze doktoratu, na placu boju pozostal Zygmunt Wojciechowski - ulubiony uczeń Balzera. Wojciechowski, zaakceptowany przez Radę Wydziału, z dniem 1 stycznia 1925 r. objął stanowisko zastẹpcy profesora w Katedrze Historii Ustroju i Prawa Polskiego. W tymże roku habilitowal się na podstawie rozprawy: Momenty terytorialne organizacji grodowej w Polsce piastowskiej (Lwów 1924), co szybko otworzyło mu droge do Katedry. W listopadzie $1929 \mathrm{r}$. został powolany na stanowisko profesora nadzwyczajnego, a od 1 stycznia $1936 \mathrm{r}$. był już profesorem zwyczajnym. Wraz z przyjściem Zygmunta Wojciechowskiego, który mial odegrać wielką rolę w integrowaniu poznań-

T Pismo Departamentu WRiOP Ministerstwa b. Dzielnicy Pruskiej, Archiwum UAM, sygn. 208/49.

${ }^{5}$ Balzer - wydaje się - już wówczas rozważał możliwość zaangażowania w niedalekiej przyszlości swego ulubionego ucznia, w tym czasie jeszcze studenta - Zygmunta Wojciechowskiego. Por. Archiwum UAM, sygn. 210/18. 
skich historyków prawa, kwestia obsady kluczowej katedry historycznoprawnej została definitywnie zakończona ${ }^{6}$.

Skomplikowaną okazała się także sprawa obsady Katedry Historii Prawa na Zachodzie Europy, utworzonej w 1920 r. Mial ją objąć wychowanek seminarium Jana Rutkowskiego - absolwent Wydziału Teodor Tyc, który w roku akademickim 1923/24 był zastępcą młodszego asystenta i potem starszym asystentem w Katedrze Historii Gospodarczej oraz Katedrze Historii Ustroju i Prawa Polskiego, i który już w 1924 r. się doktoryzował. Od czerwca $1925 \mathrm{r}$. prowadzil Tyc wyklady zlecone, od 1926 r. był zastępcą profesora w Katedrze Prawa na Zachodzie Europy. Habilitacja w marcu 1927 r. stwarzała widoki na przejęcie jej kierownictwa, co gorąco popierała Rada Wydziału. Minister WRiOP zatwierdził habilitacje 8 kwietnia $1927 \mathrm{r}$,, ale w sierpniu tegoż roku Teodor Tyc zmarl?.

Po śmierci Tyca, katedra została przekształcona w Katedrę Prawa Kościelnego, zaś wykłady historii prawa na Zachodzie Europy przejął, w ramach prac zleconych, habilitowany świeżo na Uniwersytecie Jagiellońskim - Marian Zygmunt Jedlicki, który pelnił także asystenckie obowiązki w Katedrze Historii Ustroju i Prawa Polskiego. W 1930 r. rozpoczęto starania o reaktywowanie Katedry; Rada Wydziału wszczęła postępowanie ankietowe, które de facto miało kandydaturę Jedlickiego przypieczętować. Choć gotowość przyjścia do Poznania zglosili m. in. Karol Koranyi z UJK i Iwo Jaworski z Uniwersytetu Stefana Batorego, Rada Wydziału - po zapoznaniu się z recenzjami, które nadesłali Stanisław Estreicher, Przemysław Dąbkowski i Tadeusz Silnicki - jednogłośnie opowiedziała się za Jedlickim. Ostatecznie został on od 1 października $1930 \mathrm{r}$. zastępç̨ profesora w reaktywowanej Katedrze Historii Prawa na Zachodzie Europy. Wiosną 1939 r. wszczęto postępowanie o nadanie Jedlickiemu tytułu profesora nadzwyczajnego, ale odpowiedni wniosek Senatu UP z 2 maja nie został rozpatrzony $z$ powodu wybuchu wojny. Katedra została przezeń obsadzona dopiero 31 marca 1949 r., na krótko zresztą, albowiem już w 1950 r. zostanie utworzona - jak wiadomo - Katedra Powszechnej Historii Państwa i Prawa, wlaśnie z M. Z. Jedlickim jako kierownikiem ${ }^{8}$.

\footnotetext{
Archiwum UAM, sygn. 82/510. Z opracowań por. A. F. Grabski, Zygmunt Wojciechowski $i$ historia macierzystych ziem polskich, [w:] Zygmunt Stary (1506-1548), Warszawa 1979; H. Olszewski, Zygmunt Wojciechowski - poznańska szkola historii prawa, RPEiS 1994, t. LVI, z. 3, s. 18-23; M. Sczaniecki, Zygmunt Wojciechowski 1900-1955, CPH 1955, 1. VII, z. 2, s. $385-390$.

Archiwum UAM, sygn. 211/36; por. także T, Jurek, Teodor Tyc 1896-1927, [w:] Wybitni historycy wielkopolscy, red. J. Strzelczyk, Poznań 1989, s. 209-222, tamże szczegółowy wykaz literatury.

Materialy o Jedlickim w Archiwum UAM, sygn. 208/17.
} 
Powikłana była także historia Katedry Prawa Kościelnego, która z nazwy należala wprawdzie do katedr dogmatycznoprawnych, ale w której faktycznie nauczano przede wszystkim historii prawa kościelnego. Katedra ta istniała długo tylko na papierze, gdyż wobec braku kandydata na jej kierownika pozostawała nie obsadzona, a wykład, w ramach prac zleconych, prowadził przez sześć lat regens Seminarium Duchownego w Poznaniu - ks. dr Stanisław Janasik. 3 sierpnia 1926 r., na wniosek Rady Wydziału, Ministerstwo WRiOP zmieniło ją, powracając do starej nazwy - Katedra Historii Prawa na Zachodzie Europy. Jak już była o tym mowa wyżej, Rada chciała w ten sposób umoźliwić zastępstwo w Katedrze Teodorowi Tycowi. Tymczasem w 1927 r. pojawiła się możliwość zatrudnienia w Poznaniu ucznia Władysława Abrahama - Tadeusza Silnickiego, habilitowanego we Lwowie. W związku z tym Rada i Senat uchwaliły (22 października 1927 i 3 grudnia 1927 r.) wniosek o przywrócenie Katedry Prawa Kościelnego i powołanie Silnickiego na profesora nadzwyczajnego. Ministerstwo ${ }^{9}$ zrazu zawiadomilo Rektora, że "nie moźe przychylić się do uchwały senatu co do ponownego utworzenia Katedry Nadzwyczajnej Prawa Kościelnego, zamienionej na wniosek Rady Wydziału Prawno-Ekonomicznego na Katedrę Historii Prawa na Zachodzie Europy, bo nie dysponuje środkami w budżecie", ale nie zgłosiło zastrzeżeń do uchwały Rady z 12 maja 1928 r. o ,zamianie Katedry Nadzwyczajnej Historii Prawa na Zachodzie Europy na Katedrę Nadzwyczajną Prawa Kościelnego". Być może resort został przekonany argumentem, że ks. S. Janasik $z$ uwagi na przejęcie innych obowiązków w kurii nie wyrażał zgody na dalsze prowadzenie wykładu i egzaminu, co mogło doprowadzić do ,zdekompletowania na II roku sekcji prawniczej”. Ostatecznie w grudniu Silnicki otrzymał nominację na profesora nadzwyczajnego, a 1 stycznia 1929 r. objął Katedrę i zorganizowal Zakład Prawa Kościelnego, przenosząc się na stałe do Poznania ${ }^{10}$. Rada Wydziału z maja 1939 r. nie zdążyła rozpatrzyć wniosku o powołanie Tadeusza Silnickiego na profesora zwyczajnego przed wybuchem wojny.

Wojna rozpoczeła się $w$ momencie, kiedy na Uniwersytecie Poznańskim zakończył się kilkunastoletni proces budowania struktur niezbędnych dla funkcjonowania tamtejszego środowiska historycznoprawnego, kiedy zdążyło się ono zaledwie ukonstytuować.

3. Spróbujmy odpowiedzieć na pytanie, kim byli twórcy podstaw poznańskiego środowiska historycznoprawnego. Wybierano ich starannie, spośród najlepszych, w poczuciu głębokiej odpowiedzialności za Wydział. Byli badaczami

Pismo Min. WRiOP do Rektora UP z dn. 4 I 1928 r., Archiwum UAM, sygn. 208/66.

:o Wcześniej nie godził się na to, bo miał docenturę na UJK i był we Lwowie profesorem szkoły średniej. 
najczęściej bardzo młodymi, którzy stawiali dopiero pierwsze kroki do naukowych karier, ale mogli się już wykazać osiągnięciami w swej dziedzinie; mieli dydaktyczną praktykę, dysponowali też solidnym przygotowaniem warsztatowym i erudycyjnym.

Urodzony w Krakowie w 1880 r. Zygmunt Lisowski, po studiach prawniczych i historycznych na Uniwersytecie Jagiellońskim oraz uzyskaniu doktoratu w roku 1904, udał się na kilkuletnie studia zagraniczne. Studiowal prawo rzymskie, paleografię lacińską, papirologię i historię starożytnej Grecji, a także epigrafikę lacińską i historię literatury na Wydziale Prawa w Paryżu (u A. Audiberta), w École Pratique des Hautes Études (u A. Jacoba i E. Chatelaina), w College de France (u R. Cagnata i G. Boissiera) oraz w Lipsku prawo rzymskie (u L. Mitteisa), papirologię (u U. Wilckena), egiptologię (u G. Steindorffa). Po powrocie do kraju pracował w galicyjskiej Prokuratorii Generalnej jako radca. Po habilitacji w roku 1916 na Uniwersytecie Jagiellońskim wykładał tam jako docent prawo rzymskie. Przywiózł do Poznania głęboką erudycję, akademicki szlif i spory talent organizacyjny. W znaczącym już wtedy dorobku Lisowskiego wyróżniała się monografia Studia nad sposobami nabycia wlasności w rzymskim Egipcie (1913).

Niekwestionowanym autorytetem cieszył się Jan Rutkowski - drugi z czterech członków-założycieli Wydziału. Urodził się w Warszawie w 1886 r., studia odbywal we Lwowie, gdzie shuchal wykładów takich mistrzów, jak: Oswald Balzer, Wladysław Abraham, Stanisław Zakrzewski, Bronisław Dembiński, Ludwik Finkel, Tadeusz Wojciechowski i Szymon Askenazy. Napisana u Finkla rozprawa doktorska, poświęcona skarbowości polskiej za Aleksandra Jagiellończyka, obroniona w 1909 r., ukazała się w „,Kwartalniku Historycznym"". Po uzyskaniu doktoratu Rutkowski znalazł się w składzie tzw. ekspedycji rzymskiej, zorganizowanej przez Stanisława Smolkę, jako sekretarza generalnego PAU dla spenetrowania Archiwum Watykańskiego. Studiowal w Paryżu na École Pratique des Hautes Études, uczęszczając na słynne seminaria Adolphe'a Landry'ego i Charlesa Bémonta. Przywiózł z Francji obszerną pracę: Studia nad podzialem $i$ organizacja wlasności $w$ Bretanii $w$ XVII $w^{12}$, która do dzisiaj jest niezastąpionym źródlem o tym zagadnieniu. Potem, aż do roku 1918, pracowal w Krajowym Biurze Statystycznym przy Wydziale Krajowym Galicji i Lodomerii, publikując wówczas szereg cennych studiów z zakresu statystyki własności ziemskiej. W 1914 r. ogłosił w „Ekonomiście” podstawową do dziś pracę pt. Studia

"Kwartalnik Historyczny 1909, t. XXIII, s. 1-77.

$12 \mathrm{~J}$. Rutkowski, Étude sur la répartition et l'organisation de la propriété foncière en Bretagne au XVITe siècle, 1912. Polska wersja została ogłoszona w Przeglądzie Historycznym 1913 , t. XVI, s. $67-101,218-242$ i $311-344$. 
nad polożeniem wlościan $w$ Polsce $w$ drugiej polowie XVI $w$. Habilitowal się w początkach 1917 r. na Wydziale Prawa i Umiejętności Politycznych Uniwersytetu Jana Kazimierza, uzyskując veniam legendi $\mathrm{w}$ zakresie ekonomii politycznej. W semestrze zimowym 1918/19 r. na Uniwersytecie Warszawskim wykładal dzieje gospodarcze Polski w czasach nowożytnych; równocześnie był wykładowcą w Wyższej Szkole Handlowej u boku Ludwika Krzywic$\mathrm{kiego}^{13}$. Jego naukowy autorytet na Wydziale był tak bezsporny, że Rada Wydziału już w 1921 r. wystąpiła jednogłośnie o mianowanie go profesorem zwyczajnym, mimo że trzy prace napisane po uzyskaniu ostatniego awansu $z$ roku 1919 nie zostały jeszcze opublikowane ${ }^{14}$. Zostal też od razu wybrany prodziekanem i delegatem do Senatu UP w roku akademickim 1922/23; pełnił także godność dziekana, mimo że $\mathrm{z}$ reguly niechętnie przyjmował administracyjne obowiązki.

Gruntownym przygotowaniem i niemałymi osiągnięciami mógł się w roku 1919 pochwalić Abdon Kłodziński, związany z Krakowem, gdzie urodził się w 1881 r. i w którym studiowal prawo i filozofię na UJ, w latach 1900-1907. Doktoryzował się na podstawie pracy Wojna dyplomatyczna Zygmunta Augusta z Zakonem Inflanckim. Uczestnik ekspedycji rzymskiej, debiutował wydanymi wespól z Janem Ptaśnikiem tomami Acta Cameralia, czym utorował sobie drogę do adiunktury w Krajowym Archiwum Aktów Grodzkich i Ziemskich w Krakowie. W 1913 r. zostal członkiem-korespondentem Centralnej Rady Archiwalnej w Wiedniu oraz wspólpracownikiem PAU. Jego dorobek był także natury historycznoprawnej. Pisal o stosunkach Polski i Litwy $z$ Inflantami ${ }^{15}$, o przywilejach nieszawskich ${ }^{16}$; byl autorem tablic synoptycznych statutów wiślickich, wareckiego i konstytucji lęczyckich, przygotowanych do druku wespół z Bolesławem Ulanowskim; złożył do druku w Wydawnictwach Komisji Historycznej PAU obszerny tekst o archiwum skarbca koronnego ${ }^{17}$. Było z pewnością stratą dla Wydziału, że nie potrafił Kłodzińskiego zatrzymać.

Teodor Tyc pojawil się na Wydziale Prawno-Ekonomicznym UP jeszcze jako student. Urodził się w 1896 r. w Monachium, gdzie ukończył gimnazjum,

${ }_{13}$ Por. J. T o polski, Jan Rutkowski 1886-1949, [w:] Wybitni historycy wielkopolscy, s. 214.

${ }^{14}$ Były to prace: $O$ skupie solectw w Polsce w XV i XVI w., Uwagi krytyczne o badaniach Warszawskiego Komitetu Statystycznego oraz Poddaństwo wlościan w XVIII w. w Polsce i niektórych innych krajach Europy.

is A. Kłodziński, Stosunki Polski i Litwy z Inflantami przed zatargiem z roku 1556/7, KH 1908.

${ }^{16}$ A. K lodziński, W sprawie przywilejów nieszawskich z roku 1454, [w:] Studia historyczne ku czci Wincentego Zakrzewskiego, Kraków 1908.

${ }^{17}$ Wykaz wczesnych prac Kłodzińskiego w Archiwum UAM, sygn. 210/18. 
a od $1915 \mathrm{r}$. rozpoczął studia na Wydziale Filozoficznym, poświęcając się głównie historii. Zmobilizowany do armii musiał przerwać studia, które kontynuował dopiero po zakończeniu wojny, już na Wydziale Filozoficzno-Historycznym i Wydziale Prawa UP. Do Poznania przybył ze Śląska z glową ,pełną pomysłów do badań naukowych"18 i setkami tekstów publicystycznych. Świetne przygotowanie odebrał na Uniwersytecie Monachijskim - u Grauerta, Manfreda Hellmanna i Paula Lehmanna, Aktywnie angażowal się $w$ pracę w Polskim Komisariacie Plebiscytowym, $w$ którym byl zastępcą szefa wydziału prasowego, kierownikiem sekcji niemieckiej i redaktorem głównego organu prasowego Komisariatu „Oberschlesische Grenzzeitung”. Wojciech Korfanty ocenial, że „pracą swą niestrudzoną oddał p. Tyc Teodor sprawie naszej w okresie wielkich zmagań o odzyskanie i połączenie dzielnicy piastowskiej z Macierzą - Polską, nieocenione usługi"'19. Już w czasie studiów stał się wielką nadzieją Wydziału Prawno-Ekonomicznego UP.

Zygmunt Wojciechowski miał także interesujący życiorys. Pochodził ze Stryja, gdzie urodzil się w 1900 r., a młodość spędzil w Łyczakowie. Jako ochotnik brał udział w Polskim Korpusie Posiłkowym. Świetne przygotowanie do pracy twórczej oraz poczucie służby publicznej zawdzięczal ojcu Konstantemu, który był cenionym znawcą historii literatury polskiej, a po 1918 r. - profesorem Uniwersytetu Jana Kazimierza, oraz swoim mistrzom tej Uczelni: Oswaldowi Balzerowi przede wszystkim, ale także Janowi Ptaśnikowi, Stanisławowi Zakrzewskiemu i Franciszkowi Bujakowi. Kiedy w rok po ukończeniu studiów przybył do Poznania, był już autorem trzech książek, ogłoszonych drukiem w 1924 r.: Momenty terytorialne organizacji grodowej w Polsce piastowskiej, Ze studiów nad organizacja państwa polskiego za Piastów oraz $W$ sprawie Regnum Poloniae za Wladyslawa tokietka. Były to prace ważne, dojrzale, które wejdą na trwałe do literatury historycznoprawnej. Nie przypuszczano wtedy jeszcze, że młody doktor historii prawa przyjedzie do stolicy Wielkopolski z rzadko spotykanym talentem organizatora nauki, a także zmysłem działacza politycznego i społecznego ${ }^{20}$.

Marian Zygmunt Jedlicki, urodzony w Kielcach w 1899 r., absolwent studiów prawniczych na UJ i Szkoły Nauk Politycznych w Krakowie, uczestnik wojny bolszewickiej, doktoryzowal się w 1924 r. pod kierunkiem Stanisława Estreichera. Lata 1924-1927 spędził w Paryżu, studiując w École

${ }^{18}$ T. Jurek, Teodor Tyc..., s. 155.

19 Opinia komisarza plebiscytowego Korfantego z 21 IV 1921 r. w Archiwum UAM, sygn. 211/36. W uznaniu zasług Tyc otrzymał Krzyż Kawalerski Orderu Polonia Restituta.

${ }^{20}$ Por. H. Olszewski, Zygmunt Wojciechowski 1900-1955, s. 269 i n.; tenże, Wydzial Prawa..., s. 1-16. 
de Droit pod kierunkiem François Oliviera-Martin, w École Practique des Hautes Études pod kierunkiem Ferdinanda Lota, i w École des Chartes. $\mathrm{Na}$ Zachód wyjeżdżał Jedlicki na ważne konferencje, wygłaszając referaty, które zwróciły nań uwagę badaczy, szczególnie francuskich i niemieckich. Od 1927 r. pełnil obowiązki starszego asystenta w Katedrze Historii Prawa na Zachodzie Europy UJ. W rok później habilitował się na podstawie rozprawy Podniesienie na tarczy u dawnych Germanów ${ }^{21}$. Wniosek Rady Wydziału o zatrudnienie go na Uniwersytecie Poznańskim zawierał także wysoką ocenę krytycznego studium Jedlickiego na temat Monumenta Germaniae Historica ${ }^{22}$. Oba teksty, a także liczne recenzje prac historiografii niemieckiej zapowiadały wzmocnienie profilu badawczego ośrodka poznańskich historyków prawa, coraz cześciej podejmujących badania niemcoznawcze. Jedlicki jako kandydat na Katedrę w Poznaniu był gorąco rekomendowany przez Stanisława Estreichera.

Tadeusz Silnicki również nie był homo novus. Urodzony w $1889 \mathrm{r}$., absolwent prawa, filozofii i historii sztuki we Lwowie, uczeń Oswalda Balzera, Ludwika Finkla, Karola Dembińskiego i Eugeniusza Romera, doktoryzowal się u O. Balzera pracą Prawo elekcji królów w dobie jagielloń$s k i e j^{23}$. Szerokie zainteresowania humanistyczne, obejmujące poza historią prawa i ustroju także geografię, historię sztuki i językoznawstwo, doprowadzily go w końcu do zafascynowania prawem kościelnym i kanonicznym. Kilkuletni pobyt we Francji wykorzystał przede wszystkim na ich zgłębianie, studiując m. in. u Augusta Fourniera na Sorbonie oraz w École Practique des Hautes Études. Ich rezultatem był piękny tekst w Księze Pamiqtkowej ku czci Balzera - Ordo visitationes z poczatku $X V$ w. (1925) oraz ogloszona w „Przeglądzie Teologicznym” z $1926 \mathrm{r}$. rozprawa Wplywy francuskie na polski Kościól w XI-XIII w. W roku 1927 opublikowal Silnicki prace - opus magnum, która dała mu przepustkę na Uniwersytet w Poznaniu, a mianowicie monografię Organizacja archidiakonatu $w$ Polsce ${ }^{24}$. Władysław Abraham w konkluzji opinii napisanej na zlecenie Rady Wydziału stwierdził, że lepszego kandydata na profesurę prawa kościelnego trudno sobie wymarzyćc ${ }^{25}$.

4. Pięknie i obiecująco rozpoczęta kariera nie zawsze bywa kontynuowana po uzyskaniu zawodowej stabilizacji. Pragniemy - w wielkim skrócie - zastanowić się nad wkładem wspomnianych historyków prawa w tworzenie

\footnotetext{
${ }^{21}$ Kraków 1928

22 Kraków 1927.

${ }^{23}$ Lwów 1913, w serii: Studia nad historiq prawa polskiego Lwowskiego Towarzystwa Naukowego.

24 Lwów 1927.

${ }^{25}$ Archiwum UAM, sygn. 208/66.
} 
poznańskiego środowiska historycznoprawnego. Powiedzmy sobie od razu na wstępie, że dla nich wszystkich okres poznański był najważniejszym okresem życia.

Zygmunt Lisowski pisał niewiele; samokrytycyzmem, perfekcjonizmem, poczuciem odpowiedzialności za słowo narzucał sobie niezmiernie wysokie wymagania, więc jego teksty były nieskazitelne od strony źródłowej egzegezy i doskonałe prawniczo. W 1920 r. opublikował on Prawo spadkowe, uzupelniając wcześniejsze teksty Fryderyka Zolla. W obszernym studium Zamoyski czy Sigonius. ${ }^{26}$ rozważał sporną w piśmiennictwie sprawę autorstwa 21-letniego Jana Zamoyskiego przypisywanej mu rozprawy o rzymskim senacie ${ }^{27}$; komentował Kodeks cywilny obowiqzujacy na ziemiach zachodniej Polski (1933), ogłaszał ważne studia nad wspólczesnym prawem małżeńskim - Prawo matzeńskie. Projekt ustawy (1934), i obligacyjnym: Das Recht der Schuldverhältnisse in Polen (1935). Sławę zyskał dzięki znakomitemu thumaczeniu BGB, które było uznane przez wladze II Rzeczypospolitej za urzędowe, aż do wejścia w życie nowego kodeksu cywilnego ${ }^{28}$.

Jeszcze bardziej umacniał się moralny i naukowy autorytet Jana Rutkowskiego, który w ,poznańskich” latach zdumiewal aktywnością naukową i pedagogiczną. W $1921 \mathrm{r}$. ukazała się jego od dawna gotowa do druku książka: Poddaństwo wlościan $w$ XVIII wieku $w$ Polsce $i$ niektórych innych krajach Europy - dzieło, które z uwagi na swe warsztatowe i metodologiczne walory do dziś pozostaje jedną $\mathrm{z}$ najbardziej oryginalnych $\mathrm{i}$ nowoczesnych prac $\mathrm{z}$ historii gospodarczej $\mathrm{j}^{29}$. Rutkowski był pionierem ujmowania przeszłości jako integralnej, choć pełnej powikłań całości. To łączyło go zarówno z historykami tout court, jak i z historykami prawa. W 1923 r. Rutkowski ogłosił fundamentalne studium: Zarys dziejów gospodarczych Polski w czasach przedrozbiorowych, w którym rozważał przyczyny i skutki przewrotu pańszczyźnianego w Rzeczypospolitej. Był pierwszym polskim badaczem, który zwracał uwagę na gospodarcze implikacje rozbiorów. Książka, przetłumaczona na język francuski ${ }^{30}$, spotkała się $\mathrm{z}$ entuzjastycznymi opiniami najwybitniejszych przedstawicieli szkoły „Annales” - Marca Blocha, Henri Sée czy Henri Berra, z którymi utrzymywal cały czas żywy kontakt. W redagowanej przez Berra „Revue de la Synthése historique” formułowal swój program syntezy dziejowej Le Problème de la synthèse dans l'histoire economique (1927)

\footnotetext{
2h Z. Lisowski, Lamoyski czy Sigonius?, [w:] Ksiega Pamiqtkowa ku czci Leona Pinińskiego, L. II, Lwów 1936.

27 Por. ostatnio J. Reszczyński, Nowe badania nad myślq Jana Zamoyskiego, CPH 2000, t. LII, z. 1-2, s. 323-338.

${ }^{28}$ Sylwetkę Z. Lisowskiego przedstawił K. Kolańczyk, Zygmunt Lisowski, CPH 1955, t. VII, z. 2, s. 363-384.

${ }^{29}$ Por. J. Topolski, Jan Rutkowski, s. 216.

10. 1. Rutk owski, Histoire économique de la Pologne avant les partages, Paris 1927.
} 
- takiej, w której niezbędne elementy komparatystyczne znajdują wsparcie w solidnej podbudowie teoretycznej. Wciąż podkreślal, że warunkiem sukcesu $w$ badaniach jest skuteczne neutralizowanie wpływu czynników pozanaukowych - politycznych czy ideologicznych - i starania o jak najdalej posunięty obiektywizm. Nie absolutyzując roli czynników gospodarczych, uważał, iż ważnym elementem każdej syntezy dziejowej jest zbadanie zasad, na jakich zbudowany jest podzial dochodu spolecznego. W $1938 \mathrm{r}$. Rutkowski opublikował pierwszy tom swych wieloletnich studiów w tym zakresie: Badania nad podzialem dochodów $w$ Polsce $w$ czasach nowożytnych. Rzecz stanowiła jedną z najbardziej ambitnych rozpraw, jakie na ten temat kiedykolwiek napisano ${ }^{31}$. Przygotowany do druku rękopis tomu II zaginąl niestety w czasie drugiej wojny światowej.

Kontynuowal i pogłębial badania Tadeusz Silnicki. Ukoronowaniem jego krótkiego, bo tylko 10-letniego, pobytu na przedwojennym Wydziale była obszerna rozprawa, dzięki której znalazł się w czołówce polskich historyków prawa: Dzieje i ustrój Kościola na Ślasku do końca XIV wieku, wydana w 1939 r. jako tom II, zeszyt 1 monumentalnej Historii Ślaska, wychodzącej pod redakcją Stanisława Kutrzeby, publikacja zbiorowa PAU. Dzieło to, cenne ze względu na swe warsztatowe i materiałowe wartości, odczytywane przez niektórych historyków jako glos w polsko-niemieckim dialogu historiograficznym na temat ,,prawdy o ziemi śląskiej”, doczekało się reedycji w roku $1953^{32}$. Wieńcząc badania samego Silnickiego, nie było ono zresztą wcale najważniejszym akcentem polemik toczonych $\mathrm{z}$ nauką niemiecką $w$ latach trzydziestych.

Znacznie ważniejszy glos należał do Teodora Tyca, Mariana Z. Jedlickiego oraz Zygmunta Wojciechowskiego i jego uczniów. Dzielili oni między siebie zasługę wlączenia historii prawa do szerokiego frontu badań niemcoznawczych.

Teodor Tyc dopiero rozpoczynał wielką karierę badawczą i żył zbyt krótko, by zrealizować rozległe plany, powzięte na studiach w Monachium, na frontach pierwszej wojny światowej, w działalności okresu plebiscytowego u boku W. Korfantego, oraz w czasie seminariów K. Tymienieckiego i, szczególnie, J. Rutkowskiego. Szerokie zainteresowania historią średniowiecznej kultury ukoronował zbiór studiów: $Z$ dziejów kultury $w$ Polsce średniowiecznej (1924), zawierający m. in. teksty o kronice Galla (którego autor nazywał Anonimem-Panegirystą) i o Stanisławie Ciołku. Studia nad Polską Krzywoustego i kulturą wieków średnich miały przygotować grunt pod Uzieło życia Tyca - monografię Bolesława Chrobrego. Studia we Francji zostały podsumowane monografią: Immunitet opactwa $w$ Wissembourgu ${ }^{33}$.

\footnotetext{
"J. Topolski, O nowy model historii. Jan Rutkowski (1886-1949), Warszawa 1986.

i2 Zob. J. Sawick i, Tadusz Silnicki 1889-1968, CPH 1969, t. XXI, z. 2, s. 294.

${ }^{3}$ T. Ty e, L'immunité de l'abbaye de W'issembourg, Strasbourg 1927.
} 
Dawała ona początek serii wydawniczej poświęconej historii ustroju i prawa Alzacji, i zwracała na autora życzliwą uwagę krytyki. Najwięcej uwagi poświęcał Tyc oczywiście sprawom historii stosunków polsko-niemieckich. Był jednym $\mathrm{z}$ pionierów myśli zachodniej, stając na stanowisku, że obowiązkiem nauki polskiej jest dawanie odporu nacjonalistycznej historiografii niemieckiej. Wyrazem tej postawy była książka: Poczq̨tki kolonizacji wiejskiej na prawie niemieckim $w$ Wielkopolsce (1200-1333), wydana w Poznaniu w 1924 r., a także liczne artykuły, publikowane w ,Strażnicy Zachodniej”, „Rocznikach Historycznych" czy w „Kronice Miasta Poznania"; obrazowały one walkę o kresy zachodnie, mówiły o penetrowaniu Pomorza przez Krzyżaków, były rozważaniem o kształtowaniu się stereotypu Niemca w piastowskiej Polsce. Tyc opowiadał się za dialogiem z historykami niemieckimi, opartym na rygorystycznie przestrzeganych zasadach nauki, mającym przy tym wsparcie $w$ przemyślanych strukturach. Był jednym z inicjatorów Związku Obrony Kresów Zachodnich, współpracowal z powstałym w $1925 \mathrm{r}$. Instytutem Bałtyckim. Pisal: Potrzeba nam takiej tradycji żyjacej $w$ szczególnych grodach $i$ ziemiach, która byla może za wieków średnich [...]. Niemcy już dziś bardzo żywo pracuja na terenach wielkopolskich, pomorskim, ślaskim $i$ mazurskim [...]. Tu trzeba energicznie przeciwdzialać. Trzeba rozbudzić tradycje polskie, odrębności i pamiqtki dzielnicowe [...], poustawiać tablice $i$ pomniki dla zaslużonych, wskrzesić zwyczaje ludowe, obudzić poczucie zasiedzialości slowianskiej, stworzyć mit Polski zachodniej ${ }^{34}$.

Stosunki polsko-niemieckie w późnym średniowieczu stanowiły punkt ciężkości zainteresowań także Mariana Zygmunta Jedlickiego. W drobniejszych pracach - takich jak: La création du premier archecéché polonais à Gniezno au point de vue des rapports entre la Pologne et l'Empire germanique ${ }^{35}$ czy Die Anfänge des polnischen Staates. Erwiderung ${ }^{36}$ - nade wszystko zaś w książce: Stosunek prawny Polski do cesarstwa do roku $1000^{37}$ autor ostro i krytycznie zwracal się przeciwko przerysowaniom historyków niemieckich, z Albertem Brackmannem na czele, którzy podkreślając zewnętrzne przesłanki powstania państwa Mieszka I i absolutyzując jego zależność od Niemiec, odmawiali Polsce sprzed $1000 \mathrm{r}$. charakteru suwerennego państwa. Jedlicki

${ }^{34}$ Cyt. za: T. Jurek, Teodor Tyc..., s. 158. O Tycu pisali także: J. Rutk owski, Wstep, [w:] T. Ty c, Zbigniew i Boleslaw, Poznań 1927; K. T y mi en iecki, Nekrolog, Roczniki Historyczne 1927, t. III (tamże bibliografia prac Tyca); J. W ą s ick i, Teodor Tyc (1896-1927). $Z$ dziejów ksztaltowania sie programu zachodniego w Polsce, Studia Historica Slavo-Germanica 1978, t. VII, s. 61-83. Materiały po Tycu majdują się także w Bibliotece Raczyńskich. w Poznaniu oraz w Archiwum UAM, sygn. 211/36.

${ }^{33}$ Revue historique de droit français et etranger 1933, s. 645-695.

${ }^{36}$ Historische Zeitschrift 1935, H. 3, s. 519-529.

"7. Poznań 1939, s. 180. 
odpowiadał, że przed $1000 \mathrm{r}$. łączył Polskę z cesarstwem tylko stosunek natury trybutarnej, i że otrzymując w Gnieźnie godność patrycjusza, zobowiązującą do opieki nad Kościołem, Chrobry w istocie stawał w jednym szeregu z głowami koronowanymi. Autor dowodzil, że trybut był płacony przez Polskę z Pomorza Zachodniego i stanowił odszkodowanie za zrzeczenie się przez cesarstwo praw do tej ziemi. Swoje tezy wykładał Jedlicki w wystąpieniach na międzynarodowych kongresach w Brukseli, Paryżu, Warszawie i Lowanium; będzie je rozwijal także po wojnie.

Nie tyle jednak Jedlicki, ile Zygmunt Wojciechowski nadawal ,zachodni” kierunek twórczości i wyznaczał rangę poznańskiego środowiska historycznoprawnego; kierunek ten - jego zdaniem - określała racja stanu, która wymagała obrony młodej Rzeczypospolitej przed niemieckim niebezpieczeństwem. Wojciechowski byl bliskim współpracownikiem oraz wyznawcą Dmowskiego i szczerze wierzyl, że Niemcy to śmiertelny wróg Polski. Wątek zachodni przenikał jego twórczość niezależnie od tego, o czym pisał i kiedy; zrozumiale, że jego spojrzenie wyostrzało się $\mathrm{w}$ miarę umacniania się w Niemczech rezimu Hitlera.

Przez pryzmat stosunków Polski z Niemcami analizowal Wojciechowski państwo wczesnych Piastów, a wysuwane przezeń wnioski bliskie były ujęciom zarówno geopolityki, jak i idiografizmu. Przeciwstawiał się tezie o normańskim pochodzeniu Mieszka i wielekroć powtarzal, że monarchia piastowska obejmowała tereny stanowiące terytorium pierwotnego osadnictwa polskiego. W teorii normańskiej, wedle której państwo polskie miało zawdzięczać swe powstanie najazdowi Normanów, widział polityczne uzasadnienie niemieckiej agresji na ziemie Europy słowiańskiej. Protestował też przeciwko twierdzeniu wielu badaczy niemieckich, głoszących, że Polacy nie posiadali zdolności państwowotwórczych. Jakkolwiek zgadzał się co do tego, że kolebką pierwszego państwa Piastów były Wielkopolska i Kujawy ${ }^{38}$, to równocześnie przypominal, że wedle Dagome iudex, zachodnia granica Polski obejmowała jednocześnie i Szczecin, i ujście Odry: Dzieje Polski rozpoczety sie nad Odra - głosił. W swoich studiach opublikowanych w zbiorowej Historii Ślq̨ska z 1933 r. występował przeciw tezie o wczesnośredniowiecznej germanizacji Śląska i przeciw lansowanemu w nacjonalistycznej historiografii niemiecko-pruskiej poglądowi o zaniku polskich roszczeń do Śląska za czasów Kazimierza Wielkiego ${ }^{39}$. W rozprawie pt. Rozwój terytorialny

${ }^{36}$ Myśl zachodnią Z. Wojciechowskiego przedstawia m. in. M. Mroczko, Zygmunt Wojciechowski jako historyk polskich ziem zachodnich, Przegląd Zachodni 1985, nr 1, s. 98-113; B. Pi otrowski, O Polske nad Odra i Baltykiem. Myśl zachodnia i badania niemcoznawcze, UP (1919-1939), Poznań 1987, s. 174-208; H. Olszewski, Zygmunt Wojciechowski 1900)-1955, s. 269-285.

${ }^{39}$ Historia Ślaska od najdawniejszych czasów do roku 1400, 1. I, Kraków 1933, s. 123-154, 563-604. 
Prus $w$ stosunku do ziem macierzystych Polski $i^{40}$ tak podsumował swe badania i poglądy: Macierzyste ziemie Polski to obszar od Odry i Nysy Lużyckiej po Bug, bedacy pierwotnym terytorium polskiego osadnictwa oraz najdawniejsza podstawq terytorialna państwa polskiego. „Historyczne prawa” Polski do tych ziem, które w dużej mierze rozciągają się na zachód od obszaru, który Polska odzyskała po pierwszej wojnie światowej, znajdują - jego zdaniem - pełne potwierdzenie w badaniach nie tylko historyków tout court, ale też archeologów, antropologów i językoznawców. Tytuł Polaków wywodził Wojciechowski również z dawnych dziejów europejskiej kultury: Slowianie polscy bowiem ziemie te nie tylko zasiedlili, ale również stworzyli na nich pierwiastkowq, ponadplemiennq organizacje państwowq, która te ziemie wlaczala do obrazu cywilizacyjnego ówczesnej Europy. Opuszczenie ziem nad Odrą stanowiło dlań motyw przewodni dziejów Polski; było początkiem śmiertelnego zagrożenia Polski, albowiem ziemie nad Odrą i Wisłą byly po prostu warunkiem sine qua non jej istnienia. Jeżeli zostaną one opanowane przez Niemcy, Polska zniknie z mapy Europy, podczas gdy absolutnie nie zginą Niemcy, jeżeli zostaną one przy Polsce, z tego prostego powodu, że nie są to ziemie rdzennie niemieckie. Natomiast osłabieniu ulegnie wtedy niemiecki ekspansjonizm, którego animatorem były zawsze Brandenburgia i Prusy: Rozwój terytorialny Prus w stosunku do ziem macierzystych Polski byl kamieniem wegielnym późniejszej potęi politycznej Prus. W licznych rozprawach z lat trzydziestych, takich jak: Mieszko I i powstanie państwa polskiego (1935), Jeszcze o Mieszku I - nieco polemiki i uzupetnien, w tym stowo o pochodzeniu dynastii zachodniopomorskiej (1935), Pomorze a pojecie Polski Piastowskiej (1935), Dwa ośrodki państwowotwórcze w Polsce $i$ ich zasieg geograficzny (1937), Polska nad Wisla i Odrq $w X w .(1939)^{41}$ - Wojciechowski rozwijał koncepcję ziem macierzystych Polski, przypominając, że ,klin brandenburski" i państwo krzyżackie doprowadziły do przyśpieszenia zwracania się Polski ku wschodowi, że droga od traktatu krakowskiego z 1525 r. do traktatu welawskiego byla drogą samobójczą dla Polski; że w czasie, w którym Rzeczpospolita angażowała się w konflikty na Wschodzie, na Zachodzie organizowal sie rozbójniczy organizm, który niebawem doskoczy do gardla państwa polskiego.

Koncepcja ziem macierzystych Polski nakazywała Zygmuntowi Wojciechowskiemu baczne studiowanie historiografii niemieckiej i niejako ,skazywała go" na częste polemiki $z$ jej reprezentantami. Autor nie zawsze dochowywal wierności rzymskiej maksymie, nakazującej prowadzenie dyskusji suaviter in modo, fortiter in re; dawał się ponosić temperamentowi, formował

${ }^{40}$ Z. Wojciechowski, Rozwój terytorialny Prus w stosunku do ziem macierzystych Polski (1933), [w:] tegoż, Studia historyczne, Poznań 1955; A. F. Grabski, Zygmunt Wojciechowski...

${ }^{41}$ Sylwetkę naukową Z. Wojciechowskiego przedstawil H. Olszewski w Zygmunt Wojciechowski 1900-1955, oraz w Zygmunt Wojciechowski-poznańska,.., s. 18 i n. 
pośpieszne uogólnienia, jednak znajomości dorobku historiograficznego Niemców i umiejętności prowadzenia krytyki nie można mu odmówić. Nikt $z$ historyków i prawników polskich nie obciążył tak mocno jak on politycznego serwilizmu w nauce niemieckiej, nikt nie dostrzegal równie przenikliwie jak on zagrażających Polsce z Zachodu niebezpieczeństw. Atakowal przedstawicieli pruskiej szkoły historiograficznej - G. Droysena i H. Sybla - za traktowanie ekspansji wschodniej Niemiec za podstawę mocarstwowej polityki Rzeszy i głoszenie poglądu, iż rozwiązywanie problemów cesarstwa wymaga nierozwiązywania problemów polskich. Wskazywał na wszechniemieckiego badacza Georga Belowa jako złego ducha polityki rządów Theobalda Bethmanna-Hollwega i Gustawa Stresemanna. Odważnie występowal przeciw nacjonalistycznym i rewizjonistycznym konstrukcjom, zawartym $w$ znanym, przywiezionym na Powszechny Kongres Historyków w Warszawie w roku 1933, wydawnictwie Brackmanna Deutschland und Polen ${ }^{42}$. Hitleryzm traktował jako naturalny produkt niemieckiego nacjonalizmu, nacjonalizmu przenikającego także pracę historyków; wyprowadzal go ze ,źródeł krzyżacko-brandenbursko-pruskich". W zakończeniu swej książki Polska - Niemcy. Dziesiéc wieków zmagania (opublikowanej w 1945 r., ale napisanej wcześniej), w części pisanej jeszcze przed 1939 r. dochodził do konstatacji, że antypolski program Adolfa Hitlera jest synteza poczynań wszystkich jego poprzedników, od Henryka II po Wilhelma II, a zwlaszcza doskonalq syntezq dzialań brandenburskich i krzyżackich. I dalej: Ideolog III Rzeszy p. Alfred Rosenberg chcial uksztaltować partie narodowosocjalistycznq na modle Zakonu Krzyżackiego, w krzyżackich „ordensburgach" ksztalcil przyszlych "führerów”. Prototypem ,volksdeutschów" sq - pisal - Niemcy na dworach ksiqżqt dolnoślqskich w końcu XIII w., którzy już wówczas doradzali mlodym ksiażętom ślaskim. ażeby wytepili caly naród polski, a zwlaszcza osoby duchowne $i$ rycerzy. Program eksterminacji polskiej elity narodowej jest tu już bez reszty postawiony ${ }^{43}$. W skrajnie potraktowanej konstrukcji kontynuacji w dziejach Niemiec uwidaczniała się już atmosfera zbliżającej się i potem trwającej wojny.

5. Wybitni poznańscy badacze byli oddanymi i cenionymi nauczycielami akademickimi i organizatorami nauki. Od początku zapewnili sobie poważną rolę w dydaktyce; ich przedmioty - prawo rzymskie, historia ustroju i prawa polskiego, historia gospodarcza, historia prawa na Zachodzie Europy - były wykładane na I roku obu sekcji i wchodziły w skład pierwszego egzaminu tak prawniczego, jak ekonomicznego. Wraz z Edwardem Taylorem, który wykładał historię myśli ekonomicznej oraz Antonim Peretiatkowiczem, wykładającym historię doktryn politycznych, jako

${ }^{42}$ Por. Kwartalnik Historyczny 1934, t. XLVIII, s. 18 i n.

${ }^{43}$ Z. W ojciech ow ski, Polska - Niemcy. Dziesiéc wieków zmagania, Poznań 1945, s. 258-259. 
element encyklopedii prawa i wstęp do prawa konstytucyjnego, przekazywali studentom niezbędną wiedzę teoretyczną i historyczną. Do egzaminów z dyscyplin historycznoprawnych przystępowało najwięcej studentów, a seminaria Jana Rutkowskiego, Teodora Tyca i Zygmunta Wojciechowskiego pękały w szwach.

Przedstawiciele nauk historycznoprawnych szybko też dochodzili do godności akademickich: Lisowski i Rutkowski byli dziekanami i prodziekanami, Wojciechowskiego wybrano dziekanem 26 czerwca 1939 r. Lisowski kierował Uczelnią w roku akademickim 1923/24, a potem był prorektorem. Rutkowski przewodniczył Senackiej Komisji ds. Biblioteki Glównej. Uczestniczyli też w życiu naukowym poza Uniwersytetem. Lisowski w latach 1927-1930 pełnił godność Sekretarza Generalnego Poznańskiego Towarzystwa Przyjaciół Nauk, Rutkowski był przewodniczącym Kasy im. Ryszarda Mianowskiego. Prawie wszyscy brali udział w pracach Polskiej Akademii Umiejętności, a wszyscy bez wyjątku utrzymywali $\mathrm{i}$ rozwijali żywe kontakty $\mathrm{z}$ nauką światową, przede wszystkim francuską. Symbolem wysokiej rangi, jaką osiągnęło środowisko, staky się doktoraty honorowe nadane przez UP koryfeuszom nauki historycznoprawnej - Oswaldowi Balzerowi i Władysławowi Abrahamowi ${ }^{44}$. Od życia politycznego starano się możliwie trzymać z dala. Tylko Tyc w początkach lat dwudziestych, no i Wojciechowski zgadzali się na czynne w nim uczestnictwo, ale dbali o to, by aktywność w życiu publicznym nie szkodzila rzetelności niezbędnej w dzialalności twórczej. Wojciechowski uczestniczył w pracach Towarzystwa Naukowego w Toruniu oraz Instytutu Bałtyckiego w Gdyni, dla którego stworzył program badawczy. Utrzymywal żywe kontakty z Instytutem Śląskim w Katowicach i z Towarzystwem Przyjaciół Nauki i Sztuki w Gdańsku. Prowadzil Wykłady Powszechne Uniwersytetu Poznańskiego, które w latach 1934-1939 organizowane były często $-\mathrm{z}$ jego przede wszystkim inicjatywy - w Prusach Wschodnich i na Pomorzu, w Olsztynie, Kwidzynie, Sztumie i Szczytnie. Kazimierz Kolańczyk wspominał, że o jego decyzji zostania w przyszłości badaczem zadecydowało wysłuchanie wykładu Wojciechowskiego w bydgoskim gimnazjum ${ }^{45}$. Od 1927 r. był Wojciechowski sekretarzem Komisji Historycznej PTPN. Jako działacz polityczny przeszedł znamienną ewolucję, która prowadziła od obozu narodowego do Związku Młodych Narodowców, a później do Klubu Narodowo-Państwowego, w końcu zaś - do działalności w Klubie 11 Listopada ${ }^{46}$.

6. Rozwój środowiska historycznoprawnego w Poznaniu dokumentowali wychowankowie. Nie wszyscy jego twórcy mieli uczniów. Nie zostawili ich Teodor Tyc i Abdon Kłodziński; pierwszy z powodu przedwczesnej śmierci,

4 Uchwały Senatu UP o nadaniu O. Balzerowi doktoratu h. c., 3 XII 1925 r. (wręczenie miało miejsce 12 VI $1926 \mathrm{r}$. w Poznaniu) oraz W. Abrahamowi - 16 I $1931 \mathrm{r}$. (doktorat wręczono 16 XI 1931 r. we Lwowie), por. Ksiega doktoratów h. c. w Rektoracie UAM.

${ }^{45}$ Por. życiorys K. Kolańczyka, Archiwum UAM, sygn. 819/7.

${ }^{46}$ Większość tekstów publicystycznych drukował Z. Wojciechowski na lamach Awangardy Państwa Narodowego. 
drugi $\mathrm{z}$ racji rychłego powrotu do Krakowa. Trudno by ich znaleźć w otoczeniu Lisowskiego, Jedlickiego czy Silnickiego. Bujny wzrost kadry dokonywał się natomiast na seminariach i privatissimach Jana Rutkowskiego i Zygmunta Wojciechowskiego. Obaj, niezbyt impulsywni jako wykładowcy, ale fascynujący $w$ seminaryjnych dyskusjach $z$ wybranymi, stusznie uchodzą za zasłużonych twórców szkół naukowych. Z seminarium Jana Rutkowskiego wyszli - poza Tycem - $\mathrm{m}$. in. Michał $\mathrm{Nycz}^{47}$, Stanisław Orsini-Rosenberg, Janusz Deresiewicz, Marian Kniat, Władysław Rusiński, Guntram Rolbiecki, Tadeusz Ereciński i Marian Mika ${ }^{48}$. Uczniowie skupieni wokół Wojciechowskiego - to przyszli koryfeusze nauk historycznoprawnych pierwszego powojennego ćwierćwiecza: Zdzisław Kaczmarczyk, Józef Matuszewski, Michał Sczaniecki, Kazimierz Kolańczyk, Stefan Weyman. W okresie dwudziestolecia byli asystentami-wolontariuszami, zastępcami asystentów, starszymi asystentami. Ich dysertacje odzwierciedlaly zainteresowania mistrza; solidne warsztatowo, przenikliwe w analizach i wyważone $w$ formułowanych wnioskach, weszly na stałe do literatury fachowej ${ }^{49}$. Zygmunt Wojciechowski, sam ulegając wpływom polityki, surowo strzegł, by w pracach uczniów polityka była nieobecna. Po doktoratach byli oni wysyłani za granice, z reguły do Francji. W lipcu 1939 r. zakończono drukowanie I tomu książki Zdzisława Kaczmarczyka pt. Monarchia Kazimierza Wielkiego ${ }^{50}$. Podanie autora o uznanie jej za rozprawę habilitacyjną rozpatrzyła pozytywnie Rada Wydziału, która zebrała się 1 września. Posiedzenie toczyło się już przy akompaniamencie spadających na miasto niemieckich bomb. Ostatnie poprawki w maszynopisie zaawansowanego doktoratu Kazimierz Kolańczyk omawiał z Zygmuntem Wojciechowskim w obozie dla zakładników wojennych w Poznaniu. Jak wiadomo, dzięki staraniom Z. Wojciechowskiego, praca Kolańczyka ukazała się drukiem w okupowanym Krakowie w roku 1940.

Heroiczny czas wojny stał się pomostem prowadzącym w późne lata czterdzieste, $w$ którym poznańskie środowisko historycznoprawne, wzmocnione o uczniów i uczniów uczniów jego twórców, osiągnie apogeum swego rozwoju.

${ }^{47}$ Autor fundamentalnej rozprawy Geneza reform skarbowych Sejmu Niemego. Studium z dziejów skarbowo-wojskowych z lat 1697-1717, Poznań 1938.

${ }^{48} \mathrm{~S}$. Orsini-Rosen berg, Rozwój $i$ geneza folwarku panszczyźnianego $w$ dobrach katedry gnieźnieńskiej, Poznań 1925; M. Kniat, Dzieje polożenia wlościan w Wielkim Ksiestwie Poznańskim. Przebieg prac ustawodawczych do 1932 r.; W. R u siński, Osady tzw. olędrów w dawnym województwie poznaŕskim, Kraków 1947 (praca ta obroniona została na UP w maju 1939 r.); T. Er ecińsk i, Prawo przemyslowe miasta Poznania w XVIII w., Poznań 1934; M. M ika, Studia nad patrycjatem poznañskim w wiekach średnich, Poznań 1937.

${ }^{19}$ Prace doktorskie: J. Malu szew sk i, Immunitet ekonomiczny w dobrach Kościola w Polsce do 1381 r., Poznań 1936; Z. K a c z ma r cz y k, Immunitet squdowy $i$ jurysdykcja poimmunitetowa $w$ dobrach Kosiciola w Polsce do końca XIV wieku, Poznań 1936; S. W e y ma n, Cla i drogi handlowe $w$ Polsce Piastowskiej, Poznań 1938; M. Sczaniecki, Nadania ziemi na rzecz rycerzy w Polsce do końca XIII wieku, Poznań 1939; K. Kolanczyk, Najdawniejsze polskie prawo spadkowe, Kraków 1940.

so Z. Ka czma r czyk, Monarchia Kazimierza Wielkiego, t. I: Organizacja państwa, Poznań 1939. 